\title{
UPAYA MENINGKATKAN HASIL BELAJAR KIMIA MELALUI PENERAPAN PROBLEM BASED LEARNING PADA SISWA KELAS XI SMAN 1 PARADO
}

\author{
Arif Munandar \\ Program Studi Pendidikan Kimia STKIP BIMA \\ Email: arifstkip16@gmail.com
}

\begin{abstract}
ABSTRAK
Keterampilan abad 21 menitikberatkan kepada kemampuan untuk berpikir kritis, menyelesaikan masalah, komunikasi dan kerjasama yang merupakan bagian dari HOTS (High Order Thinking Skills) atau kemampuan berpikir tingkat tinggi yang sangat perlu dimiliki oleh peserta didik sebagai bekal dalam menghadapi tantangan global. Salah satu tujuan khusus Pendidikan Pancasila dan Kewarganegaraan (PPKn) dalam Kurikulum 2013 adalah mengembangkan peserta didik agar mampu berpikir secara kritis, rasional, dan kreatif serta memiliki semangat kebangsaan serta cinta tanah air yang dijiwai oleh nilai-nilai Pancasila, Namun masalah yang terjadi adalah peserta didik lebih banyak menerima begitu saja materi yang diberikan oleh guru tanpa mempertimbangkan dengan lebih cermat, sehingga kurang mendorong peserta didik berpikir kritis. Oleh karena itu pembelajaran kimia dibutuhkan model pembelajaran yang berorientasi pada peserta didik sehingga mampu mengembangkan kemampuan berpikir kritis dan memecahkan masalah yang dihadapi dalam kehidupan sehari-hari. Problem-Based Learning (PBL) merupakan salah satu model pembelajaran yang dapat diterapkan pada pembelajaran kimia Kurikulum 2013 karena dapat mendorong peserta didik untuk berpikir kritis, keterampilan menyelesaikan masalah, menghubungkan pengetahuan mengenai masalah-masalah, dan isu-isu dunia nyata.
\end{abstract}

Kata Kunci : Penerapan Problem Based Learning Untuk meningkatkan Hasil Belajar Siswa

\section{PENDAHULUAN}

Penelitian ini bertujuan untuk meningkatkan hasil belajar siswa melalui penerapan model Problem Based Learning pada materi Hidrokarbon. Penelitian ini dilaksanakan di SMA Negeri 1 Parado pada tanggal 23 Juli 2018 sampai 04 Agustus 2018. Metode yang digunakan dalam penelitian ini adalah Penelitian Tindakan Kelas dengan siswa kelas XI IPA dengan jumlah sebanyak 25 siswa yang diajarkan dengan model pembelajaran Problem Based Learning. Konsep pokok penelitian tindakan kelas Arikunto meliputi empat komponen, yaitu perencanaan, pelaksanaan tindakan, observasi, dan refleksi. Instrumen penelitian yang digunakan adalah lembar observasi dan soal tes, diskusi kelompok, dan soal akhir siklus. Dari hasil penelitian diperoleh bahwa persentase ketuntasan hasil belajar kognitif siswa pada siklus I adalah sebesar $52 \%$ dengan nilai rata-rata 65,2 . Sedangkan persentase ketuntasan hasil belajar siswa pada siklus II mengalami peningkatan tetapi tidak mencapai standar ketuntasan menjadi sebesar $72 \%$ dengan nilai rata-rata 59,8. Sedangkan pada hasil belajar psikomotorik siswa pada siklus I adalah $60 \%$ dengan nilai rata-rata 65 . Sedangkan presentase ketuntasan hasil belajar siklus II mengalami peningkatan sebesar $84 \%$ dengan nilai rata-rata

67.4. Dari hasil tersebut dapat disimpulkan bahwa pembelajaran dengan model Problem Based Learning tidak dapat meningkatkan hasil belajar siswa pada aspek kognitif sedangkan pada aspek Psikomotorik dapat meningkatkan hasil belajar siswa.

Undang - undang No. 20 tahun 2013 tentang sistem pendidikan nasional menyebutkan bahwa Pendidikan Nasional berfungsi mengembangkan kemampuan dan membentuk watak serta peradaban Bangsa yang bermartabat dalam rangka mencerdaskan kehidupan Bangsa. Tujuan dari pendidikan nasional yaitu untuk berkembangnya potensi peserta didik agar menjadi Manusia 
yang beriman dan betakwa kepada Tuhan Yang Maha Esa, berahlak mulia, sehat, berilmu, cakep, kreatif, mandiri dan menjadi warga negara yang demokratis serta bertanggung jawab.

Permendikinas RI No. 22 Tahun 2006 tentang standar isi untuk satuan pendidikan dasar dan menengah menyatakan bahwa, struktur kurikulum SMA meliputi substansi pembelajaran yang ditempuh dalam satu jenjang pendidikan selama 6 tahun mulai kelas $X$ sampai dengan kelas XII. Kurikulum SMA memuat 8 Mata Pelajaran ( Pendidikan Agama, Pendidikan Kewarganegaraan, Bahasa Indonesia, IPS, ilmu pengetahuan Alam; seni budaya dan keterampilan; pendidikan jasmani, olah raga, dan kesehatan), Muatan lokal dan pengembangan diri (Permendiknas RI No. 22 tahun 2006).

Berdasarkan standar kompetensi dan kompetensi dasar tingkat SMA tentang standar isi untuk satuan pendidikan dasar dan menengah dijelaskan bahwa kimia merupakan ilmu universal yang mendasari perkembangan teknologi moderen, mempunyai peran penting dalam berbagai disiplin dan memajukan daya pikir manusia. Perkembangan pesat dibidang teknologi informasi dan komunikasi dewasa ini dilandasi oleh perkembangan kimia. Untuk menguasai dan menciptakan teknologi di masa depan diperlukan penguasaan Kimia yang kuat sejak dini (Permendiknas RI Nomor 22 tahun 2006).

SMAN 1 Parado merupakan salah satu SMA negeri di tengah-tengah Kecamatan Parado. pengetahuan siswa di sekolah tersebut masih tergolong rendah. Siswanya sebagian besar berasal dari kalangan menengah ke bawah. Fasilitas yang ada di sekolah tersebut kurang maksimal. Sehingga guru harus bisa mengembangkan pembelajaran yang bisa memotivasi mereka untuk belajar lebih giat, khususnya pelajaran kimia yang dinilai sulit.

Berdasarkan hasil obsevasi di SMAN 1 Parado metode yang digunakan sebagian besar adalah ceramah dengan latihan-latihan soal. Hal tersebut sesuai dengan hasil wawancara dengan 25 siswa mengatakan metode yang selama ini digunakan adalah ceramah dengan latihan-latihan soal. Para siswa juga mengatakan bahwa belum pernah sama sekali mengikuti model- model pembelajaran dengan menggunakan pembelajaran lain misalnya dengan model problem based learning.

Berdasarkan uraian - uraian tersebut diajukan suatu penelitian yang menawarkan suatu tindakan dalam proses belajar mengajar di kelas untuk meningkatkan hasil belajar siswa yang ditunjukkan dengan adanya perubahan pada indikator lebih dari $75 \%$ siswa mendapatkan nilai ulangan minimal 60 dan terciptanya suasana kelas yang kondusif untuk pembelajaran. Oleh karena itu, dilakukan penelitian beberapa pokok pikiran bagi penulis dengan judul skripsi : "Upaya Meningkatkan Hasil Belajar Kimia Melalui Penerapan Problem Based Learning Pada Siswa Kelas XI SMAN 1 Parado "

\section{METODE PENELITIAN}

Penelitian ini merupakan penelitian tindakan kelas (PTK) yang menggunakan data pengamatan langsung terhadap jalannya metode pembelajaran yang akan digunakan untuk menyampaikan materi laju reaksi di kelas. Penelitian tindakan kelas adalah penelitian yang dilakukan oleh guru, penelitian didalam kelas, dengan tujuan untuk memperbaiki kinerja guru sehingga hasil belajar menjadi meningkat.

Penelitian ini merupakan penelitian yang dianalisis melalui beberapa tahapan dalam 
siklus-siklus tindakan. Jenis penelitian ini adalah penelitian kualitatif, penelitian ini bertujuan untuk meningkatkan hasil belajar siswa dengan penerapan Problem Based Learning pada siswa kelas XI SMAN 1 Parado.

\section{Alat Pengumpulan Data}

Penelitian disamping perlu menggunakan metode yang tepat juga perlu memilih teknik dan alat pengumpulan data yang relevan. Penggunaan tehnik dan alat pengumpulan data yang tepat memungkinkan diperolehnya data yang obyektif.

Sumber data penelitian ini adalah siswa kelas XI SMAN 1 Parado, guru mitra, pelaksanaan tindakan serta lingkungan yang mendukung pelaksanaan proses belajar mengajar.

Data diperoleh dan dikumpulkan dari hasil belajar siswa yang diambil dengan memberikan tes kepada siswa. Situasi belajar mengajar pada saat dilaksanakannya tindakan diambil dengan menggunakan lembar observasi. Tanggapan siswa terhadap metode pembelajaran yang digunakan diambil dari kuesioner yang disebarkan.

Beberapa metode yang digunakan dalam penelitian ini adalah :

\section{Observasi}

Observasi dilakukan untuk mengamati keterampilan intelektual siswa dan kinerja guru selama proses belajar mengajar berlangsung dengan cara mengisi lembar observasi. Oleh hal ini, peneliti dapat mengetahui kesesuaian antara perencanaan dan pelaksanaan setiap siklus.

Tes

Tes digunakan untuk memperoleh data hasil belajar kognitif dan setelah siswa diberi penerapan model Problem Based Learning.

\section{HASIL DAN PEMBAHASAN}

\section{Hasil Penelitian}

Penelitian tindakan kelas (PTK) ini dilaksanakan di SMAN 1 Parado yang dimulai pada tanggal 23 Juli sampai dengan 04 Agustus 2018. Tujuan dari penelitian ini adalah mendiskripsikan penerapan Problem Based Lesarning untuk meningkatkan hasil belajar siswa melalu materi pokok hidrokarbon pada senyawa alkana,alkena dan alkuna serta isomer.

Dari hasil observasi dan tes, peneliti memperoeh data kualitatif dan kuantitatif diperoeh tentang aktifitas guru siswa, afektif, kognitif dan pskomotorik. Data-data tersebut kemudian dianaisis sebagai berikut

\section{Analisis Lembar Aktifitas Siswa Dan Guru Siklus I}

Hasil observasi pengamatan aktifitas guru dan siswa dapat di uraikan dalam table sebagai berikut :

Tabel 1. Data Lembar Observasi Aktivitas Siswa dan II

\begin{tabular}{|c|c|c|c|c|c|}
\hline \multirow[t]{2}{*}{ Siklus } & \multicolumn{2}{|c|}{ Aktivitas siswa } & \multicolumn{3}{|c|}{ Aktifitas guru } \\
\hline & Nilai rata - rata & Kategori & Nilai & rata- rata & Kategori \\
\hline
\end{tabular}




\begin{tabular}{|c|l|l|l|l|}
\hline I & 3 & Aktif & 3.1 & Aktif \\
\hline II & 3 & Aktif & 3.1 & Aktif \\
\hline
\end{tabular}

Lembar Pengamatan Afektif Siklus I dan II

Pengamatan sikap siswa pada siklus I dan II dapat dituliskan dalam table sebagai berikut :

Tabel 2. Data Lembar Observasi Sikap

\begin{tabular}{|c|c|c|}
\hline Siklus & \multicolumn{2}{|c|}{ Pengamatan Sikap } \\
\hline & Nilai Rata-Rata & Kategori \\
\hline I & 3,25 & Baik \\
\hline II & 3.5 & Baik \\
\hline
\end{tabular}

\section{Analisis evaluasi hasil belajar siswa Siklus I dan II Nilai Kognitif}

Adapun analisis nilai hasil belajar kognitif siswa pada siklus I dan II dapat di simpulkan dalam table sebagai berikut :

Tabel 3 Data Hasil Belajar kognitif siswa

\begin{tabular}{|l|c|c|}
\hline \multirow{2}{*}{ Keterangan data siswa } & \multicolumn{2}{|c|}{ Hasil Analisis } \\
\cline { 2 - 3 } & Suklus I & Siklus II \\
\hline Jumlah siswa & 25 & 25 \\
\hline Siswa yang tuntas & 13 & 18 \\
\hline Siswa yang tidak tuntas & 12 & 7 \\
\hline Nilai tertinggi & 85 & 85 \\
\hline Nilai terendah & 40 & 50 \\
\hline Nilai rata-rata & 65.2 & 59.8 \\
\hline \% Ketercapaian & $52 \%$ & $72 \%$ \\
\hline Keterangan & Belum tuntas & Belum tuntas \\
\hline
\end{tabular}

\section{Perbandingan Nilai Observasi Dan NIlai Hasil Belajar Siswa Siklus I dan II}

Untuk membandingkan nilai keseluruhan yang telah dianalisis pada setiap siklus, keaktifan dan ketidak tuntasan hasil belajar siswa dituliskan dalam tabel sebagai berikut :

Tabel 4 Data perbandingan nilai observasi dan Tes Siswa

\begin{tabular}{|c|l|l|l|l|}
\hline $\begin{array}{c}\text { Siklus Aktifitas } \\
\text { siswa }\end{array}$ & Aktifitas guruhgamatan & Nilai kognitif & $\begin{array}{l}\text { Nilai } \\
\text { sikap }\end{array}$ & \\
\hline
\end{tabular}




\begin{tabular}{|l|l|l|l|l|l|l|l|l|l|l|}
\hline & $\begin{array}{l}\text { Nilai } \\
\text { rata- } \\
\text { rata }\end{array}$ & Kategori & $\begin{array}{l}\text { Nilai } \\
\text { rata- } \\
\text { rata }\end{array}$ & Kategori & $\begin{array}{l}\text { Nilai } \\
\text { rata- } \\
\text { rata }\end{array}$ & Kategori & $\begin{array}{l}\text { Nilai } \\
\text { rata- } \\
\text { rata }\end{array}$ & Ketercapaian & $\begin{array}{l}\text { Nilai } \\
\text { rata- } \\
\text { rata }\end{array}$ & Ketercapaian \\
\hline I & 3 & Aktif & 3.1 & Aktif & 3.25 & Baik & 65.2 & $52 \%$ & 65 & $60 \%$ \\
\hline II & 3 & Aktif & 3.1 & Aktif & 3.5 & Baik & 59.8 & $72 \%$ & 67,4 & $84 \%$ \\
\hline
\end{tabular}

\section{PEMBAHASAN}

\section{Siklus I}

Siklus I dalam penelitian dimulai pada tangga 28 agustus 2018. Peneitian ini terdiri dari 2 jam pelajaran atau 2 kali pertemuan ( $2 \times 45$ menit). Berikut ini tahapan-tahapan dalam

\section{Perencanaan}

Berdasarkan seluruh informasi yang telah diperoleh, peneliti melakukan beberapa kegiatan dalam proses perencanaan penelitian. Kegiatan yang dilakukan pada tahap awal ini adalah membuat skenario pembelajaran yang akan dilaksanakan pada pertemuan pertama dan kedua. Pertemuan pertama berlangsung selama 45 menit yang membahas tentang alkana, alkena dan alkuna. Pada pertemuan pertama, peneliti melakukan kegiatan diskusi di dalam kelas. Pertemuan kedua berlangsung selama 45 menit yang membahas tentang pengelompokan jenis alkana, alkena dan alkuna berdasar deret homologny . Kemudian pada pertemuan selanjutnya, peneliti memberikan tes hasil belajar kepada siswa mengenai materi yang telah dibahas pada pertemuan pertama dan kedua dengnan menggunakan model Problem Based Learning yang diterapkan selama proses pembelajaran berlangsung.

Tahap Pelaksanaan

Kegiatan pembelajaran yang dilakukan dalam penelitian ini adalah dengan model Problem Based Learning. Sebelum pelajaran dimulai, peneliti sekaligus yang berperan sebagai guru kimia telah membentuk kelompok kecil yang terdiri dari 5 orang setiap kelompoknya. Setiap kelompok terdiri dari anggota yang memiliki latar belakang yang berbeda dalam hal akademik. Sebelum pelajaran dimulai, guru terlebih dahulu menjelaskan pembelajaran dengan model PBL yang akan diterapkan selama pembelajaran senyawa Hidrokarbon tersebut. Selanjutnya siswa dipersiapkan untuk melakukan kegiatan pemecahan masalah denga melakukan diskusi untuk mengidentifikasi senyawa alkana, alkena dan alkuna tersebut. Selain itu, siswa juga diberikan LKS berbasis PBL sebagai acuan dalam melaksanakan diskusi sederhana tersebut. Di sini, guru bertindak sebagai fasilitator saja dan siswa yang aktif sepenuhnya dalam mencari informasi yang dibutuhkan di dalam LKS. Kemudian setiap kelompok menyimpulkan hasil diskusinya di dalam kelas. Pembelajaran dilakukan dengan siswa pada masalah yang akan dicari jawabannya. Untuk menemukan jawaban atas permasalahan yang diajukan guru, siswa dapat mencarinya dengan melakukan kegiatan diskusi bersama teman kelompoknya sesuai acuan yang ada dalam LKS. LKS yang diberikan guru kepada setiap kelompok memiliki topik yang berbeda. Pada pertemuan ini materi yang dipelajari yaitu jenis-jenis Senyawa alkana. Alkena dan alkuna berdasarkan dalam kehidupan sehari- hari. Sebelum memasuki pembahasan, peneliti memberikan apersepsi terlebih dahulu kepada siswa sesuai dengan konsep yang akan dibahas. Setelah selesai, 
siswa bersama kelompoknya memecahkan masalah yang telah disajikan di dalam LKS untuk dicari solusi atau penyelesaiannya.

\section{Tahap Observasi}

Pada pelaksanaan kegiatan belajar mengajar siklus I, pengamatan dilakukan terhadap aktivitas guru dan siswa dan sikap siswa dalam melakukan kegiatan pembelajaran dengan model PBL. Adapaun lembar pengamatan tersebut berupa lembar observasi yang terdiri dari berbagai tahapan/langkah model PBL yang diturunkan menjadi beberapa indikator. Indikator-indikator tersebut kemudian menjadi subjek pengamatan observer yang mengobservasi kegiatan belajar mengajar dengan memberikan tanda ceklis pada kolom Ya atau Tidak serta apaila diperlukan suatu komentar dapat ditambahkan pada kolom catatan.

Berdasarkan lembar observasi dapat diketahui bahwa tidak semua tahapan model PBL dilakukan oleh siswa ketika proses pembelajaran berlangsung. Tidak semua indikator dilalui dengan baik. Selain itu, terdapat tahapan lainnya yaitu pada tahap terakhir atau ke-5, melakukan analisis evaluasi hasil kerja kelompoknya dalam pemecahan masalah. Siswa sebagian tidak melakukan tahapan tersebut, menurut catatan yang terdapat dalam lembar observasi tersebut menyebutkan bahwa, kegiatan analisis pemecahan masalah tidak dilakukan siswa dengan tidak adanya siswa yang bertanya/menanyakan hal-hal yang telah didiskusikan. Pada siklus I untuk indikator sikap siswa ternyata baik, yaitu 3.25. Hal ini cukup membuktikan bahwa model PBL menarik minat dan antusias siswa dalam memeroleh materi senyawa alkana,alkena dan alkuna. Dengan demikian siswa cukup merespon positif model PBL yang diterapkan dalam pembelajaran tersebut. Berdasarkan hasil tes yang diberikan pada siklus I terdapat 2 hasil belajar yang diukur yaitu nilai kognitif dan psikomotorik, dapat diketahui bahwa rata-rata hasil belajar siswa pada nilai kognitif siswa menunjukan nilai dibawah standar ketuntasan terdapat 12 dari 25 siswa yang belum mencapai KKM. KKM yang ditetapkan dalam penelitian ini adalah 65 dan indikator keberhasilan penelitian adalah $75 \%$. Keberhasilan yang dicapai siswa dalam siklus I ini adalah sebesar 52\%. Angka ini belum memenuhi indikator keberhasilan penelitian yang mencapai 75\%. Berdasarkan hasil tersebut, penelitian harus berlanjut ke siklus selanjutnya. Sedangkan nilai tes hasil belajar yang nilai ratarata hasil belajar pada nilai psikomotorik siswa menunjukan nilai dibawah standar ketuntasan terdapat 10 dari 25 siswa yang belum mencapai nlai KKM, sehingga untuk menyempurnakan nilai tersebut penelitian ini akan berlanjut ke siklus II.

\section{Tahap refleksi}

Setelah dilakukan observasi terhadap aktivitas belajar siswa dalam proses pembelajaran, maka dilakukan refleksi. Refleksi bertujuan untuk mengidentifikasi hal-hal positif dan masalahmasalah yang muncul pada siklus pertama ini dan akan diperbaiki pada siklus kedua dengan memberikan perlakukan-perlakuan (treatment) tertentu. Berdasarkan data hasil observasi, pembelajaran dengan model pembelajaran berbasis masalah (Problem Based Learning) cukup efektif untuk diterapkan dalam meningkatkan keaktifan siswa pada proses pembelajaran dan pembentukan pengetahuan baru di dalam kelas.

\section{Siklus II}

Siklus II pada penelitian ini dilakukan pada 30 Juli dan 04 Agustus yang membahas tentang 
materi isomer pada molekul n-butana dan 2-metipentana. Sama dengan siklus I yang dilaksanakan dengan 2 kali pertemuan, siklus II dilakukan juga dengan dua kali pertemuan atau 2 jam pelajaran ( $2 \times 45$ menit).

\section{Tahap Perencanaan}

Berdasarkan refleksi siklus I, penerapan penggunaan model PBL cukup efektif dalam meningkatkan keaktifan siswa pada proses pembelajaran. Dari hasil evaluasi dilakukan di akhir siklus I dilihat dari tes hasil belajar masih terdapat 13 siswa yang belum mencapai kriteria ketuntasan minimal (KKM) sebesar 75 pada nilai kognitif dan 10 siswa yang belum mencapai kriteria ketuntasan minimal (KKM) pda nilai Psikomotorik. Aktivitas dan sikap siswa di dalam kelas sudah aktif dan baik, tetapi masih perlu ditingkatkan lagi seperti kurangnya kerjasama antar anggota kelompok, masih terdapat anggota kelompok yang belum memiliki kontribusi yang lebih dalam menyumbangkan ide pemecahan masalah yang dihadapi. Pada siklus II ini terdiri dari dua pertemuan dan dua jam pelajaran kimia yang membahas proses dan cara menganaisis senyawa n-butan 2-metil propana. Pada siklus II ini, peneliti mencoba untuk memberikan pengertian yang lebih kepada siswa seperti penjelasan mengenai tahap-tahap pembelajaran berdasarkan model PBL yang diterapkan serta mengatur waktu agar pas dengan jadwal yang telah ditentukan.

\section{Tahap Pelaksanaan}

Sebelum pelajaran dimulai, terlebih dahulu guru memberikan motivasi maupun apersepsi mengenai materi yang akan dibahas. Karena, konsep pada pertemuan ke-3 di siklus II ini membahas tentang cara-cara menganalisis senyawa n-butana dan 2- metilpropana. Kemudian, guru memorganisasi siswa dalam belajar dengan memberikan perintah kepada setiap kelompok untuk mulai membaca wacana masalah yang terdapat dalam LKS pertemuan ke-2. Guru memberikan arahan atau instruksi kepasa segenap siswa untuk menjawab dan memecahkan masalah secara berkelompok dan memfasilitasi kegiatan diskusi kelompok tersebut.

\section{Tahap pengamatan / Observasi}

Pada pelaksanaan kegiatan belajar mengajar siklus II, pengamatan/observasi sama halnya dengan pengamatan yang dilakukan di siklus I. Adapun pengamatan yang dilakukan ialah terhadap aktivitas belajar mengajar yang berkaitan dengan langkah- langkah pembelajaran model PBL. Observer sebagai pengamat melakukan check-list pada lembar observasi yang tersedia. Berdasarkan observer yang dilakukan dapat diketahui bahwa tidak semua tahapan model PBL dilakukan oleh siswa ketika proses pembelajaran berlangsung. Terdapat satu indikator pada tahap keempat yaitu melibatkan dirinya aktif dalam kegiatan diskusi kelompok. Menurut observer, ketika tahap pengembangan dan penyajian hasil karya terdapat beberapa anggota dari masing- masing kelompok yang kurang terlibat dalam kegiatan diskusi kelas. Namun, hasil observasi pada siklus I dengan indikator sama dapat dipenuhi, pada hasil observasi siklus II hanya terdapat satu saja indikator yang belum dipenuhi. Oleh karena itu, pengamatan aktivitas pembelajaran pada siklus II dan siklus I sama-sama aktif dalam mengikuti pelajaran. Berdasarkan hasil tes pada siklus II diperoleh nilai rata-rata 59.8 dan 11 siswa yang belum mencapai nilai KKM. Selain itu, indikator keberhasilan penelitian ini juga belum tercapai nilainya masih dibawah standatar sebesar $72 \%$ pada nilai kognitif dan pada nilai psikomotorik memiliki nilai rata-rata 67,4 dan nilai standar ketuntasan sebesar $84 \%$, nilai ini jauh lebih besar dari pada nilai siklus I, keberhasilan penelitian yang telah ditetapkan sebelumnya yaitu $75 \%$. Oleh karena itu, penelitian ini hasil belajarnya pada 
nilai kognitif tidak meningkat tetapi pada nilai psikomotorik meningkat.

\section{Tahap Refleksi}

Berdasarkan hasil analisis dan evaluasi data pada siklus II, diperoleh gambaran bahwa menggunkan model PBL sudah efektif tetapi ada kendala-kendala yang menghambat hasil belajar kadang tidak tuntas tetapi, bisa diminimalisir ketika siswa tidak malas dalam melakukan segala hal tersebut. Berdasarkan analisis dari tiap- tiap siklus diatas, terlihat bahwa hasil siklus-siklus ada yang tidak meningkat dan ada yang meningkat. Data dari hasil observasi pada siklus I menunjukan bahwa nilai rata- rata aktifitas siswa sebesar 3 tidak mengalami peningkatan juga pada Siklus II tetapi nilai rata-ratanya sama yaitu sebesar 3 tetapi masuk dalam kategori aktif. Pada aktifitas guru juga seperti itu pada siklus I dan siklus II nilai rata-rata yang dihasilkan sebesar 3.1 dan juga masuk dalam kategori aktif, dan pada pengamatan sikap siswa, memliki nilai rata-rata sebesar 3.25 pada siklus I dan pada siklus II memiliki nilai rata-rata sebesar 3.5 dan masuk dalam kategori baik. Selanjutnya analisis pada hasil belajar siswa yang diukur pada dua aspek yang pertama aspek kgnitif dan aspek yang kedua psikomotorik, pada aspek pertama yaitu aspek kognitif siswa pada siklis I memiliki nilai rata-rata sebesar 65.2 dan ketercapaian ketuntasanya sebesar $52 \%$ sehingga pada siklus I ini aspek kognitif pada pencapaian nilai KKMnya tidak mengalami peningkatan dan dilanjutkan ke siklus II, pada siklus II ini aspek kognitif memiliki nilai rata-rata sebesar 59.8 dan ketercapaian ketuntasanya sebesar $72 \%$, pencapaian nilai KKMnya berselisih beberapa porsen saja dengan Standar ketuntasan yang ditetapkan tetapi pada siklus II ini tetap saja disebut tidak mengalam peningkatan karena standar ketuntasan maksimalnya itu sebesar 75\%. Dan selanjutnya analisis hasil belajar pada aspek yang kedua yaitu aspek psikomotorik, pada nilai aspek psikomotorik ini memiliki nilai rata-rata sebesar 65 dan standar ketercapaianya $60 \%$ pada siklus I, sehingga pada analisis hasil belajar pda aspek kognitif ini masih perlu disempurnakan di siklus II, dan pada siklus II nilai rata-rata sebesar 67.4 dan stabdar ketercapaiannya sebesar $84 \%$, sehingga pada siklus II ini aspek kognitif pada hasil belajar siswa mengalami peningkatan.

Berdasarkan hasil yang diperoleh dari keseluruhan penelitian tersebut menunjukan bahwa upaya meningkatkan hasi belajar kimia melalui penerapan model Problem Based Learning pada siswa kelas XI SMAN 1 Parado adalah pada aktifitas guru dan siswa meninjjukan kategori aktif, aspek sikap siswa menunjjukkan kategori baik dan aspek kognitif hasil belajarnya tidak tuntas dan apek kognitifnya tundas dan mengalami peningkatan.

\section{KESIMPULAN}

Berdasarkan hasil penelitian dan hasil pembahasan dapat ditarik kesimpilan bahwa upaya meningkatkan hasil belajar siswa melalui penerapan Problem Based Learning pada siswa kelas XI SMAN 1 Parado taun pelajaran 2018/2019. Hal ini dapat dilihat dari dua siklus. Pada siklus I nilai rata-rata hasil belajar pada aspek kognitif sebesar 65,2 dan standar ketuntasannya $75 \%$ dan mengalami peningkatan pada siklus II tetapi tidak nebcapai pada standar ketercapaian sebesar $72 \%$ dan memiliki nilai rata-rata 59.8 dan pada aspek psikomtorik nilai rata-rata sebesar 65 dan standar ketercapaian $60 \%$ pada siklus I dan pada siklus II nilai rata-rata sebesar 67,4 dan standar ketercapaian sebesar $84 \%$ hasil belajar psikomotorik meningkat. Dengan demikian ada peningkatan signifikan dari siklus I ke siklus II. 


\section{DAFTAR PUSTAKA}

Amir, M. Taufiq. 2009. Inovasi Pendidikan Melalui Problem Based Learning.

Jakarta: Prenada Media Group.

Arikunto Suharmi, 2002. Prosedur Penelitian Suatu Pendekatan Praktis.Jakarta: Rineka Cipta.

Tri Anni Chatarina.2005. Psikologi Belajar. Semarang : Unnes Press

Fitria. 2015. "Pengaruh Model Pembelajaran PBL(Problem Based Learning) Melalui Metode Proyek terhadap Hasil Belajar Siswa pada Materi Hasil KaliKelarutan Kelas XI SMAN 12 Banda Aceh", Skripsi. Banda Aceh: FakultasTarbiyah dan Keguruan UIN Ar-Raniry.

Haryanto,Ari. 2009. Untuk SMA / MA Kelas XI. Jakarta : Pusat Perbukuan Pendidikan Nasional.

Ibrahim, Muslimin. 2012. Pembelajaran Berdasarkan Masalah. Surabaya: Unesa University Press.

Nurkencana, Sudiati, 2003. Interaksi belajar Mengajar. Jakarta. Yhudistira. Pemendiknas. No. 22 Tahun 2006. Standar Isi Pendidikan. Jakarta

Rasma, Mauri. 2016 "Pengaruh Model Pembelajaran Problem Based Learning (PBL) dengan menggunakan Macromedia Flash pada Materi Asam Basa terhadap Hasil Belajar Siswa Kelas XI MAS Darul Ihsan Aceh Besar". Skripsi. Banda Aceh: Fakultas Tarbiyah dan Keguruan UIN Ar-Raniry

Rusman. 2013. Model-model Pembelajaran: Mengembangkan Profesionalisme Guru. Jakarta: PT RajaGrafindo Persada

S. Margon. 2010. Metodologi Penelitian Pendidikan. Jakarta: PT Rineka Cipta.

Slameto. 2010. Belajar dan Faktor-faktor yang Mempengaruhinya. Jakarta : Rinekacipta

Sugiyono. 2004. Statistik Untuk Penelitian. Bandung. : Alfabeta.

Nurul Zuriah.2003. Penelitian Tindakan Kelas (Classroom Based Research) dalam Bidang Pendidikan dan Sosial. Malang : Bayumedia Publising. 